\title{
Character Module Development Through Minangkabau Traditional Story Based Literacy by Using Role Playing Method at Kindergarten in Padang
}

\author{
Nurhaini ${ }^{1}$ and Delfi Eliza ${ }^{2}$ \\ ${ }^{1}$ Early Childhood Education Department, Faculty of Education, Padang State University, Padang, Indonesia, \\ Nurhaini.spdaud.2013@g mail.com \\ ${ }^{2}$ Early Childhood Education Department, Faculty of Education, Padang State University, Padang, Indonesia, \\ deliza.zarni@gmail.com
}

\begin{abstract}
This research is motivated by lack of a module or a storybook based on traditional story Minangkabau and lack of teacher knowledge about the ways and means of reading stories to children so that the literacy of children is less developed, and also there is no modules about the traditional story of Minangkabau which could be a reference for teachers in planning lessons to develop values and character of children. The purpose of this study is the first, to explain the process of developing valid character modules (in terms of feasibility content). Second, to explain the process of the development of practical character modules (in terms of ease of use). Third, to explain the process of developing an effective code module (seen from the results of learning for children and activities) that are used in kindergarten II Padang. The theory used in this study were (1) The nature of Early Childhood (2) Folklore Minangkabau (3) The nature of Literacy (4) Role Playing Method (5) Learning Module. This type of research is research and development or Research and Development (R \& D) which aims to develop a module that is valid, practical, and effective. Step-by-step design for the development stage Definition (Define), Stage Design (Design), stage of development (Develop). Made the development of learning modules that have been designed through three stages of validation, test the practicalities, and test the effectiveness of this module can be reference for teachers in developing children's character. This type of research is research and development or Research and Development (R \& D) which aims to develop a module that is valid, practical, and effective.
\end{abstract}

Keywords: character, Literacy, role play, the traditional story minangkabau

\section{INTRODUCTION}

Kindergarten (TK) is fundamental formal education institutions because it was held with the aim of facilitating their growth and development. Honor, (2017: 379) declare early childhood is an individual who is undergoing a process of growth and development is very rapid. According to Bier, (2004: 3) character complex set of characteristics that allow individuals to act. Character development begins with the knowledge of children can be children's moral development, moral feelings, and act morally.

According to Eliza, Delpi (2017: 157) character development is a growing moral values which includes three components: (1) moral knowledge (knowing), (2) the attitude of moral consciousness (Affect), (3) moral action (action). The next character is closely associated with literacy. According to Liu \& Channell, (2015: 987) literacy consists of a number of skills and abilities, he can have a comprehensive impact on reading and listening and have severe consequences for a person's success in the future.
According to Eliza, (2017: 287) described as child literacy skills to interact with storybooks and presenting it to be written and read. The characters are portrayed is a matter of culture, because culture is very attached and close to the child.

Based on observations and interviews conducted in the second half of 2018 dated October 18 to 30 kindergarten Padang presented some problems as follows: (1) Lack of a module or a story book story-based traditional Minangkabau (2) Lack of teacher knowledge about how and step reading stories to children that affects the development of child literacy (3) the absence of a module on Minangkabau traditional story that could be a reference for teachers in planning lessons develop character values in children. Wongpinunwatana, (2013: 74) playing the role of an experience-based instruction. Role playing is a learning method that invites children to be directly involved in learning in the field. Furthermore, observations which focused on kindergarten Ekasakti that the application of role playing only $20 \%$ or 1 times in the first 
half since the implementation of the role playing pretty difficult and require experience teachers.

There are some studies related to storytelling and role play in teaching. For instance, Putri \& Ardi (2013) promote to used storytelling to improve speaking, McSharry \& Jones (2000) about role play in science. However, those studies focus on adult learners. Meanwhile, it can also be used for children.

The problems of this study are as follows. What is the process of character development through literacy-based module Minangkabau traditional story using role playing in kindergarten Padang valid in terms of the feasibility of the content? Following that, in terms of ease of use? Next, seen from the results of learning for children and activities that are used in kindergarten Padang? "

As for the purpose of this study is as follows. (1) to explain the process of the development of character modules (in terms of feasibility content). (2) to explain the process of the development of character modules (in terms of ease of use). (3) to explain the process of the development of character modules (seen from the results of learning for children and activities) that are used at kindergarten in Padang.

Products developed in this study is a module-based literacy character through traditional Minangkabau story using role playing in kindergarten Padang valid, practical, and effective.

The importance of development in this study are as follows. First, simplify the teacher to present learning materials in the form of understanding the story to the child because of existing modules in the form of a book. Secondly, through the module code through traditional story-based literacy Minangkabau using role playing children are easier to understand the story. Third, with the availability of modules varies, then the child will get the benefits that learning becomes more fun activities. Fourth, the more the child will get the chance to learn by looking, guess what is in the picture.

1. Early childhood education programs

According Partini (2010: 1) early childhood education is the development efforts carried out continuously from birth to eight years old. Early childhood education is the golden period or periods which is very important for children. Developments that are faced in this period is very influential on the development of children, especially in children's brain development and pisikis (Martini, 2018: 16),

2. Folklore Minangkabau

According to Eliza Delfi, (2017: 284) the importance of introducing the values of Minangkabau story character and identity by using a picture book story-based traditional Minangkabau based on folklore to develop children's literacy needs to be done so that children can distinguish the good deed and the bad. According to Hasibuan, (2013: 103) building character is the soul carve or sculpt such a manner that uniquely shaped, attractive and distinct or distinguishable by the person.
Values contained in Minangkabau traditional story

a. Value of education

Are the values that make up the story and the character of the community awareness. The social value in the mix and spoken word

b. Culture value

Knowingly or not the story/kaba, have contributed to the wealth of tradition and modern literature. Keberdaan mem-enriched literary culture cultural values.

c. value of compliance

A rich tradition of living and thriving

in Minangkabau

d. Value of religion / religious

Everything works submitted to Allah Almighty

Bohlin \& Ryan (2001) has defined the people with good character as an individual who knows the good, love the good, and do good. According to Pala (2011: 23) character education is a national movement that creates a school that fosters young generation of ethical, responsible, and caring.

Ministry of Education through the Ministry of Education (2006), explains the nine-character education among which are (1) love God and all ciptannya, (2) selfreliance and responsibility, (3) honesty / trustworthy and diplomatic, (4) respectful and civil, (5) benefactors, like helping and gontong assistance and cooperation, (6) selfreliant and work hard, (7) leadership and justice, (8) kind and humble (9) tolerance, peace and unity. According to Delfi Eliza, (2017: 284) the importance of introducing the values of Minangkabau story character and identity by using a picture book story-based traditional Minangkabau based on folklore.

3. Literacy

Defining the term literacy course should include elements that surround the language itself, the social and cultural situation(Widyastuti, 2017: 101), According to Liu \& Channell, (2015: 987) literacy consists of a large number of skills and abilities, he can have a comprehensive and powerful impact for a person's success in the future.

4. The method of Role Playing

Playing the role (role playing) lessons with the show, or show events experienced by people Role playing is also known as pretending play, fantasy, fantasy, or symbolic. (Triyanto, 2010), According to Sumariah, (2019: 74)) Steps a game of role playing is generally comprised of (1) the determination of tea and objectives of the game of role playing, (2) determine the form of role playing in the form of role play, psychodrama or sociodramas, (3) the teacher as a "director" member outlines the to child's situation will dimulasikan (4) then the teacher designates who plays into what or as anyone, (5) the teacher gives time for the cast to prepare, (6) carry out a simulation at a time and place that has been predetermined, (7) since this is just a game, the teacher members permaikan suggestions and valuable 
advice for the child during the game progresses, (8) retraining for the perfection of the simulation.

$$
\text { 5. Learning Module }
$$

Sabri (2012: 143-144) argues modules one complete unit consisting of a series of learning activities to achieve the objectives that have been formulated in accordance with the stacking RPPH before. According to the Ministry of Education (2012), as a means of learning modules which contain material, limitations, and evaluate systematically designed to achieve the expected competencies accord with the purpose or RPPH expected. Some aspects that must be considered in assessing a module that includes validation, practicalities, and effectiveness.

\section{1) Indicator Module Valid}

Purwanto (2011: 114), the validity related to the ability to measure precisely something that is desired to be measured. Arikunto (2010: 278) states validation of a series of activities that aim to commercialize something in order to be valid, valid, and reliable.

\section{2) Practical Module Indicators}

Practicalities may mean that the instrument used is easy to use. According to Joseph (2005: 103), the practicalities of covering the costs used is not too high, easily administered, and when used appropriately and not too long.

\section{3) Indicators Effective Modules}

According Vembrianto (2012: 72), is a measurement of the effectiveness or the achievement of learning outcomes that have been achieved by the child after learning modules. According Sudjana and Ahmad Rival (2007: 134) states module can be said to be effective at least $80 \%$ of the objectives have to be mastered.

\section{DISCUSSION}

This type of research is research and development or Research and Development ( $R$ \& D) which aims to develop a module that is valid, practical, and effective. Sugiyono (2012: 407) states that the method of research and development or Research and Development (R \& D) research methods used to produce a specific product and test the effectiveness of the product. Step-by-step through the code module development plan based literacy Minangkabau traditional story using role playing the following.

1.The definition phase (Define)

a. Analysis Beginning of the End

The initial analysis of the end of the beginning of attitudes, knowledge, and skills, beginning a wholly owned subsidiary in order to achieve the objectives listed in the curriculum. Based on preliminary analysis of information obtained final.

b.Analysis of Children

The analysis is the study of the characteristics of learners that includes the child's level of cognitive development, the ability of background knowledge, and socio-cultural background of the child. c. Task analysis

In this analysis there is a structural analysis of the contents. structural analysis of the contents of the review of the curriculum set on learning. Analysis of the structure of the content is the analysis of the curriculum.

d.Material analysis

material analysis aims to determine the content and the learning materials needed. Based on the analysis of the curriculum, the obtained indicators and learning objectives. The results of the analysis as a reference to formulate learning materials and contained in RPPH.

e. Analysis Learning Objectives

Analysis carried out to obtain the goal of learning objectives to be achieved on learning. The learning objectives are developed based on indicators developed RPPM and RPPH.

2. Stage Design (Design) a. Constructing based on Test Criteria

Designing learning modules based on the format and use learning strategies, namely to develop the characters and story-based literacy Minangkabau people. Aspects developed in the validation of customized indicators and product specifications have been set.

b.Electoral Media

Media selection is done to obtain tools that can be used to convey or deliver messages of learning.

c. Format Selection

The format of writing customized learning modules to guide development of teaching materials from the Ministry of Education (2012). The writing format module contains components that guide learning, competence, content, information support, exercise, work instructions, and evaluation. The writing format guided learning modules to guide the development of teaching materials and

3. Development stage (Develop)

At this stage, is the development of learning modules that have been designed through three stages of validation, test the practicalities, and test the effectiveness of the code module development through story-based literacy traditional Minangkabau using role playing at kindergarten in Padang.

1) Phase practicalities Module

2) Stage Effectiveness Module

\section{A. Trial Product}

After revision of the design of the product so the next step of the research is the development of product design. Product trials conducted to determine the effectiveness of the product developed. This trial will be conducted at kindergarten in Padang. 
B. Subject Test

Product trials conducted in kindergarten in Padang, amounting to 16 people.

C. Instrument Data Collectors

The instrument used to collect research data consisted of a questionnaire the validity of the validator/experts, questionnaire practicalities of teachers and children, child activity observation sheet, and practice test sheet.

D. Data analysis technique

1. Analysis Questionnaires

The questionnaires were analyzed by describing the results of qualitative interviews that were supported by the data quantitative. Interviews were conducted by researchers with the teacher. Things were asked relating to the end of the preliminary analysis.

2.Validity Analysis Products

To determine the validity of the products, used Likert scale calculations. By using a Likert scale, the variables to be measured are translated into sub variable, then sub variable

3. Analysis of the practicalities of Products

Test data practicalities of products (modules) can be seen from a questionnaire completed by the teacher and the child. The questionnaire drawn up in the form of Likert Scale. According Riduwan (2012: 12), Likert Scale used to measure attitudes, opinions, and perceptions of a person or group of events or social phenomena.

\section{CONCLUSION}

From the description above can be concluded that the character development in early childhood can be developed through the model-based books of traditional stories that contain character values

In the implementation of role playing learning method is a method that is more appropriate because the child directly portray character and the character to be achieved

Learning steps are performed in an effort to improve children's ability to develop speaking skills through modules, including: (1) increase the courage to speak the child in a way children listen to stories from the teacher to the position parallel to the teacher's views that characterize, even retell the form of the game, (2) increasing fluency and expression of the child by optimizing the concentration of children at the time of listening to the account, (3) increase the ability of children to retell the story by way of direct practice.

Based on the conclusions on the above results, it can be put forward suggestions as follows:

\section{For Kindergarten Teacher}

Teachers can use the module Character Based Literacy Through Stories Traditional Minangkabau, as a medium of learning in improving the ability of children in kindergarten desert city.

2. For Parties Kindergarten (TK)

Modules Character Based Literacy Through Stories Traditional Minangkabau in the learning process can be used as a medium to enhance the ability of children and improve the quality of education in kindergarten.

\section{REFERENCES}

[1] Arikunto, Suharsimi. (2010). Penilaian Program Pendidikan. Jakarta: Bina Aksara.

[2] Bohlin, Farmer, Ryan. (2001) Building Character in Schools: A Resource Guide (California: Jossey Bass )

[3] Bier, M. W. B. A. M. C. (2004). Research Based Character Education. Iieseaiicii BASEI) CIIAHAC]'ER EDUCATION, 00 (January), ANNALS, AAPSS, 591, January 2004.

[4] Depdiknas. (2006) Pengajaran Pendidikan Anak Usia Dini. Depdiknas.

[5] Depdiknas. (2012). Panduan Pengembangan Bahan Ajar. Jakarta: Direktorat Jenderal Pendidikan Dasar.

[6] Eliza, D. (2017). Pengembangan Model Pembelajaran Karakter Berbasis Cerita Tradisional Minangkabau Untuk Anak Usia Dini. Pedagogik, 3(1), 153-163.

[7] Liu, D., \& Channell, L. (2015). The Predominance of Literacy Activities in Urban Early Childhood Education. Universal Journal of Educational Research 3(11): 897-905, 2015 DOI: 10.13189/Ujer.2015.031116

Http://Www.Hrpub.Org, 3(11), 897-905. https://doi.org/10.13189/ujer.2015.031116.

[8] McSharry, G. \& Jones, S. (2000). Role-play in science teaching and learning. School Science Review, 82(298),73-82.

[9] Mulia, A. (2017a). Pendidikan Karakter Anak Usia Dini Melalui Metode Role Playing (Main Peran). Prosiding Seminar Nasional Tahunan Fakultas Ilmu Sosial Universitas Negeri Medan Tahun 2017 Vol. 1 No. 1 2017, Hal. 379-383 PENDIDIKAN. Program Studi Pendidikan Dasar Program Pascasarjana Universitas Negeri Medan Corresponding, 1(1), 379-383.

[10] Pala, A. (2011). The Need For Character Education. International Journal Of Social Sciences And Humanity Studies Vol 3, No 2, 2011 Issn: 1309. 
8063 (Online). Celal Bayar University Educational Sciences Department Millet Cad. No: 14 Gaziemir/Izmir-Turkey E-Mail:, 3(2), 23-32.

[11] Partini (2010). Pengantar Pendidikan Anak Usia Dini. Yogyakarta: Grafindo Litera Media.

[12] Purwanto. (2011). Evaluasi Hasil Belajar. Yogyakarta: Pustaka Pelajar.

[13] Putri, R. \& Ardi, H. (2013). Using Digital Storytelling to Teach Speaking at Senior High School. Journal of English Language Teaching 2 (1), 282-288

[14] Sabri, A. (2012). Strategi Belajar Mengajar. Ciputat: Quantum Teaching.

[15] Sudjana, Nana dan Ahmad Rivai. (2007). Teknologi Pendidikan. Bandung: Sinar Baru Algesindo.

[16] Sugiyono. (2012). Metode Penelitian Kuantitatif, Kualitatif, dan R\&D. Bandung: Alfabeta.

[17] Sumariah, S. (2019). Pelaksanaan Pendidikan Karakter pada Anak Usia Dini di TK Harapan Bunda Cimahi (The Implementation Of Charahcter Education In Early Childhood In TK Harapan Bunda In Cimahi). Al-Afkar, Journal for Islamic Studies Http://Al-Afkar.Com. EISSN :2614-4905, P-ISSN :2614-4883., 3(1), 182-198.

https://doi.org/10.5281/zenodo.2550907.

[18] Riduwan. (2012). Skala Pengukuran Variabelvariabel Penelitian. Bandung: Alfabeta.

[19] Trianto. (2010). Model Pembelajaran Terpadu. Jakarta: Bumi Aksara.

[20] Vembrianto. (2011). Pengantar Pengajaran Modul. Yogyakarta: Yayasan Pendidikan Paramita.

[21] Widyastuti, A. (2017). Peningkatan Literasi Anak Usia 4-6 Tahun Melalui Bahan Ajar Membaca, Menulis, dan Berhitung Untuk Guru Tk. Abdimas Talenta, 2(2), 100-108.

[22] Wongpinunwatana, N. (2013). Enhancing Information Systems Auditing Knowledge with Role-Playing Game: An Experimental Investigation. International Education Studies;
Vol. 6, No. 9; 2013 ISSN 1913-9020 E-ISSN 1913-9039 Published by Canadian Center of Science and Education. Thammasat Business School, Thammasat University, Bangkok, Thailand., 6(9), 72-82. https://doi.org/10.5539/ies.v6n9p72.

[23] Yusuf, A. Muri. (2005). "Dasar-dasar dan Teknik Evaluasi Pendidikan: Pilar Penyediaan Informasi dan Kegiatan Pengendalian, Penjamin Serta Penetapan Mutu Pendidikan Terhadap Berbagai Komponen Pendidikan”. (buku tidak diterbitkan). Padang: Universitas Negeri Padang. 